\title{
Study on yield parameters of major Date Palm (Phoenix dactylifera L.) cultivars planted in Sindh, Pakistan
}

\author{
Muhammad Mahmood-ur-Rahman Jamro ${ }^{1 *}$, Ghulam Mustafa Laghari², \\ Mahmooda Buriro ${ }^{2}$ and Nisar Ahmad Soomro ${ }^{1}$ \\ 1. Pakistan Agricultural Research Council Islamabad, \\ 2. Sindh Agriculture University, Tandojam, Pakistan \\ *Corresponding author's email: mrjamro@yahoo.com \\ Citation \\ Muhammad Mahmood-ur-Rahman Jamro, Ghulam Mustafa Laghari, Mahmooda Buriro and Nisar Ahmad Soomro. \\ Study on yield parameters of major Date palm (Phoenix dactylifera L.) cultivars planted in Sindh, Pakistan. Pure \\ and Applied Biology. Vol. 5, Issue 1, 2016, pp1-4. http://dx.doi.org/10.19045/bspab.2016.50001
}

\begin{tabular}{llll}
\hline Received: 23/06/2015 & Revised: 07/12/2015 & Accepted: 08/12/2015 & Online First: 10/12/2015 \\
\hline \hline
\end{tabular}

\section{Abstract}

To evaluate the yield parameters of different Date palm cultivars, the present study was conducted at Date Palm Research Station Kot Diji, Khairpur (Mirs), Sindh, Pakistan. The results revealed that, highest average number of bunches $\left(20.15\right.$ plant $\left.^{-1}\right)$ were recorded in Aseel cultivar. However, the lowest average number of bunches $\left(12.14\right.$ plant $\left.^{-1}\right)$, Fruit size $(3.72 \mathrm{~cm})$ and yield (99.73 kg plant ${ }^{-1}$ ) was recorded by Hussaini Date palm cultivar. The maximum weight of single

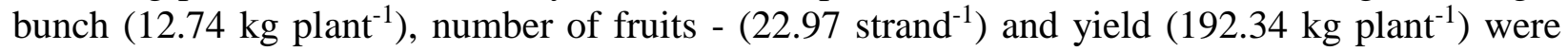
observed in Karbalain. However the lower fruit diameter $(2.16 \mathrm{~cm})$ was recorded in Karbalain. The minimum weight of single bunch - $\left(6.54\right.$ plant $\left.^{-1}\right)$ and number of fruits $\left(11.77\right.$ strand $\left.^{-1}\right)$ were recorded in Kupro. While the highest single fruit weight $(12.31 \mathrm{~g})$ and the higher Fruit diameter $(3.05 \mathrm{~cm})$ were recorded in same cultivar. The higher number of strand $\left(110.53 \mathrm{bunch}^{-1}\right)$ was recorded in cultivar - Muzawati as well as lower number of strand $\left(66.53 \mathrm{bunch}^{-1}\right)$ was recorded in Sawero. However, the lowest single fruit weight $(5.37 \mathrm{~g})$ was observed in Fasli Date palm cultivar.

Key words: Date palm; Yield parameters; Fruit characters; Yield.

\section{Introduction}

The Date palm (Phoenix dactylifera $\mathrm{L}$.) is a dioecious, perennial and monocotyledon fruit tree. It is strongly heterogeneous and diversified plant [1]. Date palm is an income generating crop having potential of staple food [2]. It provides fiber, carbohydrates, minerals, vitamins and also having anti mutagenic and anti-carcinogenic properties [3-7]. Date palm is the major fruit crop of
Pakistan and ranked $5^{\text {th }}$ for production in the world [8]. In conventional date processing, dry or soft dates are eaten as whole fruit, seeded and stuffed, or chopped and used in a great variety of ways: as ingredients in cereals, puddings, breads, cakes, cookies, ice cream, and confectionaries. Recent innovations include chocolate-covered dates and products such as sparkling date juice, used in some Islamic countries as a non- 
alcoholic version of champagne, for special occasions and religious times such as Ramadan [9]. This fruit tree is considered as an essential constituent of farming systems in dry and semi-arid regions and is apposite for both small and large scale farming [10]. Its cultivation is a good alternative to advance the food and economic status of individuals [11]. Date palm tree has abundant usages and has a vital role in ecological upgrading of the deserts [12].

The area under Date palm cultivation in Pakistan is 90.1 thousand hectare with production of 524.0 thousand tons and the area under Date palm cultivation in Sindh is 32.7 thousand hectare with production of 268.6 thousand tons [13]. In Sindh province, district Khairpur is major Date palm growing area having 29477 hectares under Date palm cultivation, even though the area is increasing day by day. It is therefore district Khairpur enjoys highly prestigious position in terms of Date palm cultivation and known as queen of Date palm in Pakistan. Khairpur, Kingri and Kot Diji are three major Date palm growing areas of this district. It is a day light fact that only a single variety Aseel is circulating in the commercial activities of Pakistan. However, there are many cultivars of Dates which are growing in Khairpur like Fasli, Karbalain, Sawero and Kupro which are differentiated from one another on the basis of morphological characters and production. But these Date palm cultivars are depreciated in the commercial activities. Therefore the purpose of study is to figure out the best cultivars among these ignored cultivars of Date palm.

\section{Materials and methods}

This study was comprised on eight Date palm cultivars which are grown at Date Palm Research Station Kot Diji, Khairpur (Mirs), Sindh, Pakistan. During the fruiting season of 2014, female trees were selected, based upon age consistency $(20-25$ years old), uniform in size, growth and vigour. Selected plants were kept under regular schedule of cultural practices. The experiment was set up as a completely randomized with three replications. The data for different parameters i.e. number of bunches plant ${ }^{-1}$, weight of single bunch $\operatorname{plant}^{-1}(\mathrm{~kg})$, number of strand bunch $^{-1}$, number of fruits strand ${ }^{-1}$, single fruit weight $(\mathrm{g})$, fruit diameter $(\mathrm{cm})$, fruit size $(\mathrm{cm})$, yield plant $^{-1}(\mathrm{~kg})$, assessed at maturity stage. Fruit weight was measured using an analytical balance and calculated as mean of 10 fruits.

The collected data analyzed for analysis of variance (ANOVA). For mean discrimination, Duncan's Multiple Range Test (DMRT) was applied on all the crop traits through MSTAT-C package [14].

Table 1. Response of major yield contributing parameters of Date palm cultivars.

\begin{tabular}{|c|c|c|c|c|c|c|c|c|}
\hline $\begin{array}{l}\text { Name of } \\
\text { cultivar }\end{array}$ & $\begin{array}{l}\text { Number } \\
\text { of } \\
\text { bunches } \\
\text { plant }^{-1} \\
\end{array}$ & $\begin{array}{l}\text { Wt; of single } \\
\text { bunch plant } \\
1 \\
(\mathrm{~kg}) \\
\end{array}$ & $\begin{array}{l}\text { Number } \\
\text { of strand } \\
\text { bunch }^{-1}\end{array}$ & $\begin{array}{l}\text { Number } \\
\text { of fruits } \\
\text { strand }^{-1}\end{array}$ & $\begin{array}{l}\text { Single fruit } \\
\text { weight } \\
\text { (g) }\end{array}$ & $\begin{array}{l}\text { Fruit } \\
\text { diameter } \\
(\mathrm{cm})\end{array}$ & $\begin{array}{l}\text { Fruit size } \\
\text { (cm) }\end{array}$ & $\begin{array}{l}\text { Yield } \\
\text { plant }^{-1} \\
(\mathbf{k g})\end{array}$ \\
\hline Aseel & $20.15 \mathrm{a}$ & $9.14 \mathrm{c}$ & $96.33 \mathrm{~b}$ & $19.37 \mathrm{c}$ & $8.64 b$ & $2.83 \mathrm{~b}$ & $4.10 \mathrm{abc}$ & $184.00 \mathrm{~b}$ \\
\hline Fasli & $17.14 \mathrm{~cd}$ & $11.14 \mathrm{~b}$ & $71.53 \mathrm{e}$ & $17.57 \mathrm{~d}$ & $5.37 \mathrm{~d}$ & $2.56 \mathrm{c}$ & $3.86 \mathrm{bc}$ & $191.01 \mathrm{a}$ \\
\hline Karbalain & $16.73 \mathrm{~d}$ & $12.74 \mathrm{a}$ & $90.93 \mathrm{c}$ & $22.97 \mathrm{a}$ & $6.68 \mathrm{c}$ & $2.16 \mathrm{~d}$ & 4.03abc & $192.34 \mathrm{a}$ \\
\hline Sawero & $18.14 \mathrm{c}$ & $9.340 \mathrm{~cd}$ & $66.53 \mathrm{f}$ & $14.57 \mathrm{e}$ & $11.24 \mathrm{a}$ & $2.55 \mathrm{c}$ & $4.50 \mathrm{a}$ & $162.89 \mathrm{~d}$ \\
\hline Hussaini & $12.14 \mathrm{f}$ & $8.540 \mathrm{e}$ & $76.53 \mathrm{~d}$ & $18.77 \mathrm{~cd}$ & $6.44 \mathrm{~cd}$ & $2.23 \mathrm{~d}$ & $3.72 \mathrm{c}$ & $99.73 \mathrm{f}$ \\
\hline Kupro & $18.12 \mathrm{c}$ & $6.540 \mathrm{f}$ & $77.73 \mathrm{~d}$ & $11.77 \mathrm{f}$ & $12.31 \mathrm{a}$ & $3.05 \mathrm{a}$ & $4.29 \mathrm{ab}$ & $112.69 \mathrm{e}$ \\
\hline Muzawati & $19.24 \mathrm{~b}$ & $9.54 \mathrm{~cd}$ & $110.53 \mathrm{a}$ & $21.17 \mathrm{~b}$ & 8.19 b & $2.61 \mathrm{c}$ & $4.18 \mathrm{abc}$ & $175.02 \mathrm{c}$ \\
\hline Shakri & $15.14 \mathrm{e}$ & $8.54 \mathrm{e}$ & $77.53 \mathrm{~d}$ & $12.33 \mathrm{f}$ & $7.51 b c$ & $2.81 \mathrm{~b}$ & $3.96 b c$ & $120.93 \mathrm{~d}$ \\
\hline SE & 0.313 & 0.145 & 0.370 & 0.509 & 0.367 & 0.052 & 0.162 & 5.018 \\
\hline LSD (5\%) & 1.036 & 0.482 & 1.226 & 1.687 & 1.217 & 0.173 & 0.536 & 16.619 \\
\hline
\end{tabular}

In each column, means followed by common letter are not significantly different at $5 \%$ probability level. 


\section{Results and discussion}

The results presented in (Table. 1) revealed that the highest average number of bunches (20.15 plant $^{-1}$ ) were recorded in Aseel followed by $19.24,18.14,18.12$, Muzawati, Sawero, Kupro respectively. However, the lowest number of bunches (12.14 plant $^{-1}$ ) was observed in Hussaini. The variation among the number of bunches might be due to cultivar characters, because each cultivar has different yield potential. The maximum weight of single bunch (12.74 kg plant $\left.{ }^{-1}\right)$ was observed in Karbalain followed by 11.14, 9.54, 9.34, and 9.14, Fasli, Muzawati, Sawero, and Aseel. Whereas, the minimum weight of single bunch (6.54 plant $^{-1}$ ) was recorded by Kupro. The increase in weight of single bunch in Karbalain cultivar was due to more number of fruits strand ${ }^{-1}$.

The higher number of strand (110.53 bunch $^{-}$ 1) was recorded in Muzawati followed by 96.33, 90.93, 77.73, 77.53, Aseel, Karbalain, Kupro, Shakri respectively. While the lower number of strand (66.53 bunch $\left.{ }^{-1}\right)$ was recorded in Sawero. The maximum number of fruits (22.97 strand $\left.^{-1}\right)$ was observed in Karbalain followed by 21.17, 19.37, 18.77, 17.57 Muzawati, Aseel, Hussaini and Fasli respectively. Whereas, the minimum number of fruits (11.77 strand $^{-1}$ ) was recorded by Kupro. The highest Single fruit weight $(12.31 \mathrm{~g})$ was recorded in Kupro followed by $11.24,8.64,8.19$, Sawero, Aseel and Muzawati, respectively. However, the lowest Single fruit weight $(5.37 \mathrm{~g})$ was observed in Fasli. The results of this research also in general agreement with the findings of [15], who reported the fruit weight $23.80 \mathrm{~g}$ of Samany and $11.06 \mathrm{~g}$ of Bent-Aisha Date palm varieties.

The higher Fruit diameter $(3.05 \mathrm{~cm})$ was recorded in Kupro followed by 2.83, 2.81, 2.61, 2.56, Aseel, Shakri, Muzawatiand Fasli respectively. The lower Fruit diameter $(2.16 \mathrm{~cm})$ was recorded in Karbalain. These results are in collaboration with the findings of [16] who reported that the maximum breath of $3.31 \mathrm{~cm}$ by cultivar Samany. The maximum fruit size $(4.50 \mathrm{~cm})$ was observed in Sawero followed by 4.29, 4.18, 4.03, 3.96 Kupro, Muzawati, Karbalain and Shakri, whereas, the minimum Fruit size $(3.72 \mathrm{~cm})$ was recorded by Hussaini, according to research findings of [15], the fruit length ranged from 2.80- $5.92 \mathrm{~cm}$ in Aglany and Zaghloul cultivars,

The maximum yield (192.34 kg plant ${ }^{-1}$ ) was observed in Karbalain followed by 191.01, 184.00, 175.02, 120.93 Fasli, Aseel, Muzawati and Shakri whereas, the minimum yield (99.73 kg plant ${ }^{-1}$ ) was recorded by Hussaini. Results for the yield plant ${ }^{-1}$ shows that the Aseel variety produced low yield at some extent as compare to Fasli and Karbalain but the fruit of these cultivars recorded small in size and diameter. It is also fact that small fruit size is considered as limitations in the popularity of fruit among the farmers as well as in the market. Therefore Aseel cultivar considered more popular than other Date palm cultivars in Sindh. These findings also establish the findings of [17-19].

In the light of above study it can be concluded that all the above studied Date palm cultivars varied among the yield parameters and fruit characters. But only the Muzawati cultivar found in resemblance with Aseel in major yield contributing parameters. This study will be of great interest in local germ plasm management, conservation and would be helpful for commercial utilization of Date palm.

\section{Authors' contributions}

Conceived and designed the experiments: MMR Jamro, Performed the experiments: MMR Jamro \& GM Laghari, Analyzed the data: M Buriro \& MMR Jamro, Contributed reagents/materials/analysis tools: NA Soomro, Wrote the paper: MMR Jamro \& GM Laghari. 


\section{References}

1. Fakir SPC \& Munier (1992). Origine de la culture surpalmierdattieretsa propagation en Afrique. Fruits 36: 437450.

2. Al-Shahib W \& Marshall RJ (2003). The fruit of the date palm: it's possible use as the best food for the future. Int J Food Sci Nutr 54: 247-259.

3. Mohamed AE (2000). Trace element levels in some kinds of dates. Food Chemis 49, 107-113.

4. Vayalill PK (2002). Antioxidant and antimutagenic properties of aqueous extract of date fruit. J Agri \& Food Chem 50, 610-617.

5. Al-Farsi M, Alasalvar C, Morris A, Barron M \& Shahidi F (2005). Compositional and sensory characteristics of three native sun-dried date varieties grown in Oman. J Agri \& Food Chem 53, 7586-7591.

6. Ishurd O \& Kennedy JF (2005). The anticancer activity of polysaccharide prepared from Libyan dates. Carbohydrate Polymers 59: 531-535.

7. Baloch MK, Saleem SA, Ahmad K, Baloch AK \& Baloch WA (2006). Impact of controlled atmosphere on the stability of Dhakki dates. Swiss Soc Food Sci \& Technol 39, 671-676.

8. FAOSTAT (2012). Food and Agriculture Organization of the United Nations. (http://faostat.fao.org/site/339/default.asp $\mathrm{x})$.

9. Wikipedia (2006). Date palm. Available on:http://en.wikipedia.org/wiki/Datepalm

10. Khushk AM, Memon A \& Aujla KM (2009). Marketing channels and margins of dates in Sindh, Pakistan. J Agri Res 47:293-308.

11. Hassan S, Bakhsh K, Gill ZA, Maqbool A \& Ahmad W (2006). Economics of growing date palm in Punjab. Pakistan Int
J Agri Biol 8:788-792.

12. Chao CT \& Krueger RR (2007). The date palm (Phoenix dactlifera L.): overview of biology, uses and cultivation. Hort Sci 42:1077-1082.

13. MNFS \& R, (2010-11). Agricultural statistics of Pakistan, Date palm area and production. Government of Pakistan, Ministry of national food security and research (economic wing) Islamabad, 45.

14. Gomez KA \& Gomez AA (1985). Statistics for Agricultural Research (Second Edition). John Willey and Sons, New York, 680.

15. Mansour HM (2005). Morphological and Genetic Characterization of Some Common Phoenix dactylifera L. Cultivars in Ismailia Region.M. Sc. Thesis Botany Department, Faculty of Science, Suez Canal University.

16. Sakr MM, Abu Zeid IM, Hassan AE, Baz AGIO \& Hassan WM (2010). Identification of some date palm cultivars by fruit characters. Indian J Sci Tech. 3(3): 338- 342.

17. Ahmad M, Bashir MA, Chaudhry NA, Shakir MA \& Khan M (2004). Performance of date varieties under Bahawalpur conditions. Sarhad J Agric 20: 39-42.

18. Al-Obeed RS, Harhash MA \& Fayez NS (2005). Effect of bunch thinning on yield and fruit quality of Succary date palm cultivar grown in the Riyadh region. $J$. King Saud Univ Agric Sci 17(2): 235249.

19. Ismail B, Haffar I, Baalbaki R, Mechref Y \& Henry J (2006). Physico-chemical characteristics and total quality of five date varieties grown in the United Arab Emirates. Int J of Food Sci and Tech, 41(8): 919-926. 